\title{
Prehnite as an indicator of productive fractures in the shallow reservoir, Kakkonda geothermal system, northeast Japan
}

\author{
Yoichi Muramatsu* and Nobuo Doi** \\ *Department of Liberal Arts, Faculty of Science and Technology, \\ Science University of Tokyo, Noda, Chiba 278-8510, Japan \\ ** JMC Geothermal Engineering Co., Ltd., \\ Ukai, Takizawa-mura, Iwate 020-0172, Japan
}

\begin{abstract}
Large amounts of chips of hydrothermal minerals were ejected with steam and hot water at the initial opening of a shallow production well (Well-4; total depth of $1448 \mathrm{~m}$ ) after well completion at the Kakkonda geothermal field, northeast Japan. The ejectas yield important information to specify an indicative hydrothermal mineral of the productive fractures as an essential factor on development of the geothermal energy resource.The ejectas consist mainly of euhedral quartz, epidote (pistacite mole fraction of 0.22 to 0.25 ), prehnite and wairakite. The quartz and calc-silicate minerals precipitated as drusy minerals in a productive fracture where is connected to a feed point of the well. On the microscopic observation of the ejectas, cavities in the fracture are seen to have been partly self-sealed with precipitation of these minerals. Thermodynamic consideration shows that the fossil reservoir fluids are in equilibrium with epidote or prehnite-wairakite as well as quartz and calcite, whereas the present reservoir fluids are in equilibrium with prehnite as well as quartz and calcite. The decreasing of temperature and $\mathrm{f}_{\mathrm{CO}_{2}}$ in the reservoir fluids has shifted the calc-silicate mineral stabilities from epidote or prehnite-wairakite to prehnite. The process may result from the degassing of $\mathrm{CO}_{2}$-rich reservoir fluid. Prehnite appears to be a good indicator of the productive fractures in the shallow reservoir of the Kakkonda geothermal field.
\end{abstract}

\section{Introduction}

Well productivity in geothermal fields depends on the permeability of open fracture around the path of the present reservoir fluid. Existence of hydrothermal minerals precipitating in the fissure will reduce the permeability by self-sealing effect. It is therefore important to specify the minerals and the place of their formation on development of geothermal energy resources.

Large amounts of chips of hydrothermal minerals precipitated in a productive fracture were ejected with steam and hot water at the initial opening of a shallow production well (Well-4) at the Kakkonda geothermal

\footnotetext{
Y. Muramatsu，村松容一，muramatu@ rs.noda.sut.ac.jp Corresponding author

N. Doi，土井宣夫，doi@geothermal.co.jp
}

field, northeast Japan. In this paper, we report the mineralogy and microthermometry of hydrothermal minerals in their ejectas, drill cores and cuttings from the well. Furthermore based on these data and the thermodynamic consideration for calc-silicate minerals-reservoir fluids equilibrium, we discuss the evolution of temperature and $\mathrm{f}_{\mathrm{CO}_{2}}$ in the reservoir fluid, and also give an effective indicator of productive fractures in the shallow reservoir.

\section{Geologic Setting and Geothermal System}

In the Kakkonda geothermal field, northeast Japan, the Kakkonda I geothermal power plant $(50 \mathrm{MWe})$ has been in operation since 1978, and afterwards the Kakkonda II geothermal power plant $(30 \mathrm{MWe})$ began to generate in 1996 (Fig. 1). The geology and geothermal system of the field have been well investigated by Japan Metals and Chemicals Co., Ltd. (JMC), the developer of 


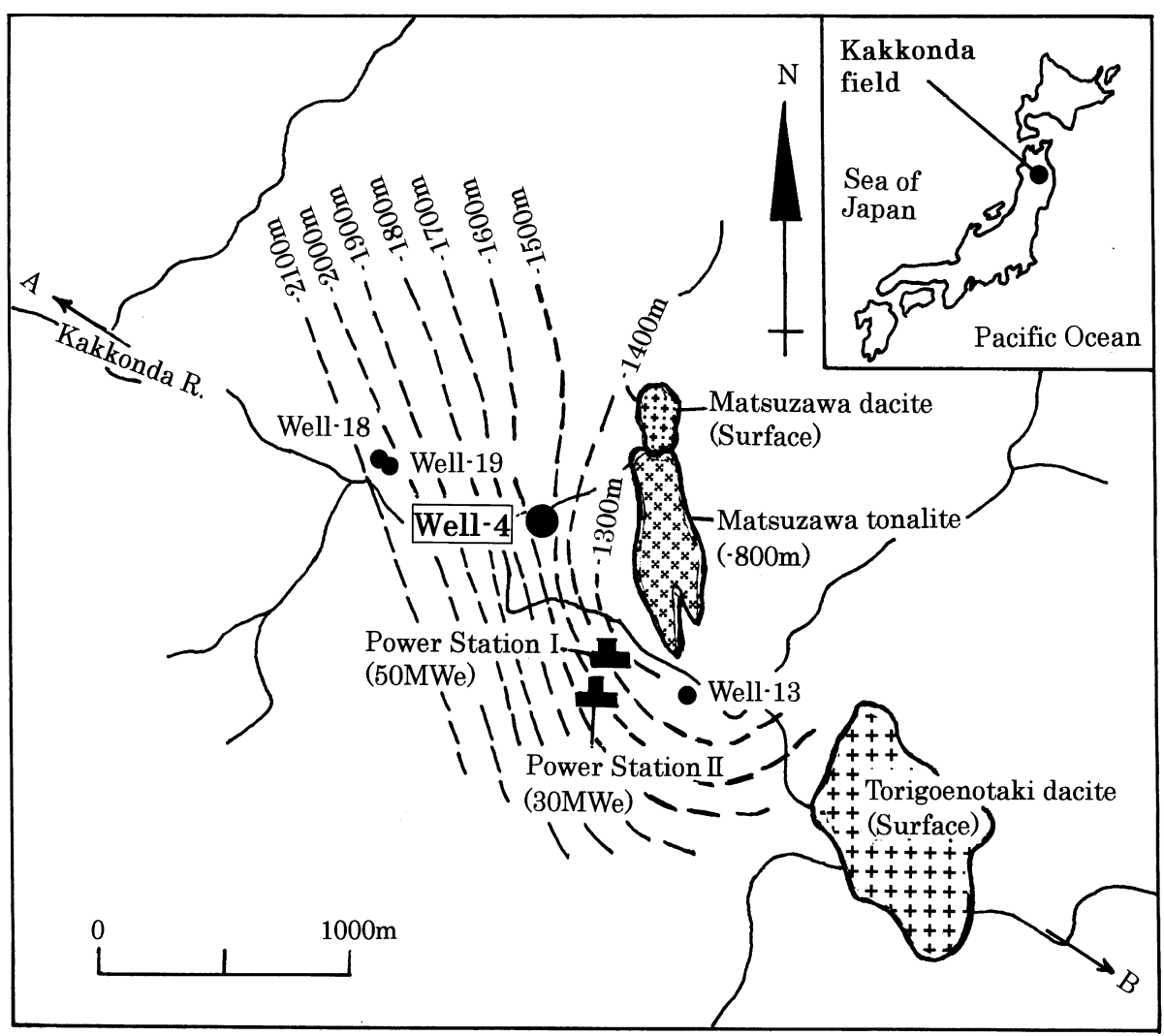

Figure 1. Locations of intrusions (modified from Uchida et al., 1996) and well head of Well-4 at the Kakkonda geothermal field.

Contours show the western and southern margins of the Kakkonda granite in meters above sea level. The Matsuzawa dacite and Torigoenotaki dacite are at the ground surface, and the Matsuzawa tonalite at $-800 \mathrm{~m}$ above sea level. Solid circle indicates the location of the well head.

the field, and described by Nakamura and Sumi (1981), Sato (1982), Doi et al. (1988, 1998), Kanisawa et al. (1994), Muramatsu and Komatsu (1995a) and Uchida et al. (1996). The rocks of the field consist of the preTertiary formations, Miocene formations such as Obonai Formation, Kunimitoge Formation, Takinoue-onsen Formation and Yamatsuda Formation, Pliocene-Pleistocene Tamagawa welded tuff and Quaternary volcanic rocks in ascending order (Fig. 2). In addition, many intrusive rocks were emplaced in these formations.

Pre-Tertiary formations consist of slate, sandstone and andesitic tuff. Miocene formations consist mainly of sedimentary rocks such as andesitic tuff, dacitic tuff, shale and siltstone. The intrusive rocks consist of old volcanic and hypabyssal rocks, and Quaternary plutonic rocks. The old volcanic and hypabyssal rocks such as Torigoenotaki dacite $(\mathrm{K}-\mathrm{Ar}$ ages of $4.9 \pm 1.0 \mathrm{Ma}$; Tamanyu,1980), Matsuzawa dacite and porphyrite intruded the Miocene formations (Sato, 1982). Moreover, the concealed plutons such as the Matsuzawa tonalite and the Kakkonda granite intruded the Miocene and pre-Tertiary formations, respectively. The Matsuzawa tonalite is slightly metamorphosed (Doi et al., 1988), and the margin of the pluton grades into quartz porphyrite. The pluton has a top of less than $-740 \mathrm{~m}$ above sea level (Doi et al., 1998) and is elongated to N$\mathrm{S}$ direction with about $300 \mathrm{~m}$ in maximum width at -800 $\mathrm{m}$ above sea level (Fig. 1). Based on the fluid pressure estimated by the microthermometry of the fluid inclusions in igneous quartz of the Matsuzawa tonalite and the Kakkonda granite, Muramatsu and Komatsu (1995b) deduced that the Matsuzawa tonalite intruded the Miocene formations prior to the Kakkonda granite (slightly younger than $0.7-1.0 \mathrm{Ma}$; Kanisawa et al., 1994) by a single magmatic activity. Doi et al. (1998) also deduced that the Matsuzawa tonalite is the early stage Kakkonda granite based on the geological and geochemical data of the two granitic rocks.

The Kakkonda geothermal system has been developing after emplacement of the Kakkonda granite (Kato and Doi, 1993; Muramatsu and Komatsu, 1995a), which is considered to be a possible heat source of the system (Uchida et al., 1996). It consists of two reservoirs with different temperature and permeability: the shallow reservoir above approximately $1500 \mathrm{~m}$ depth has temperature of 230 to $260^{\circ} \mathrm{C}$ with high permeability, while the deep reservoir has temperature of 300 to over $350^{\circ} \mathrm{C}$ with less permeability (Kato and Doi, 1993; Fig. 2). High temperature fluid has been flowing up in the upflow zone from the northwest deep reservoir of the field during hydrothermal activity after emplacement of the Quaternary intrusions such as the Matsuzawa tonalite and the Kakkonda granite (Muramatsu and Komatsu, 1995a). 


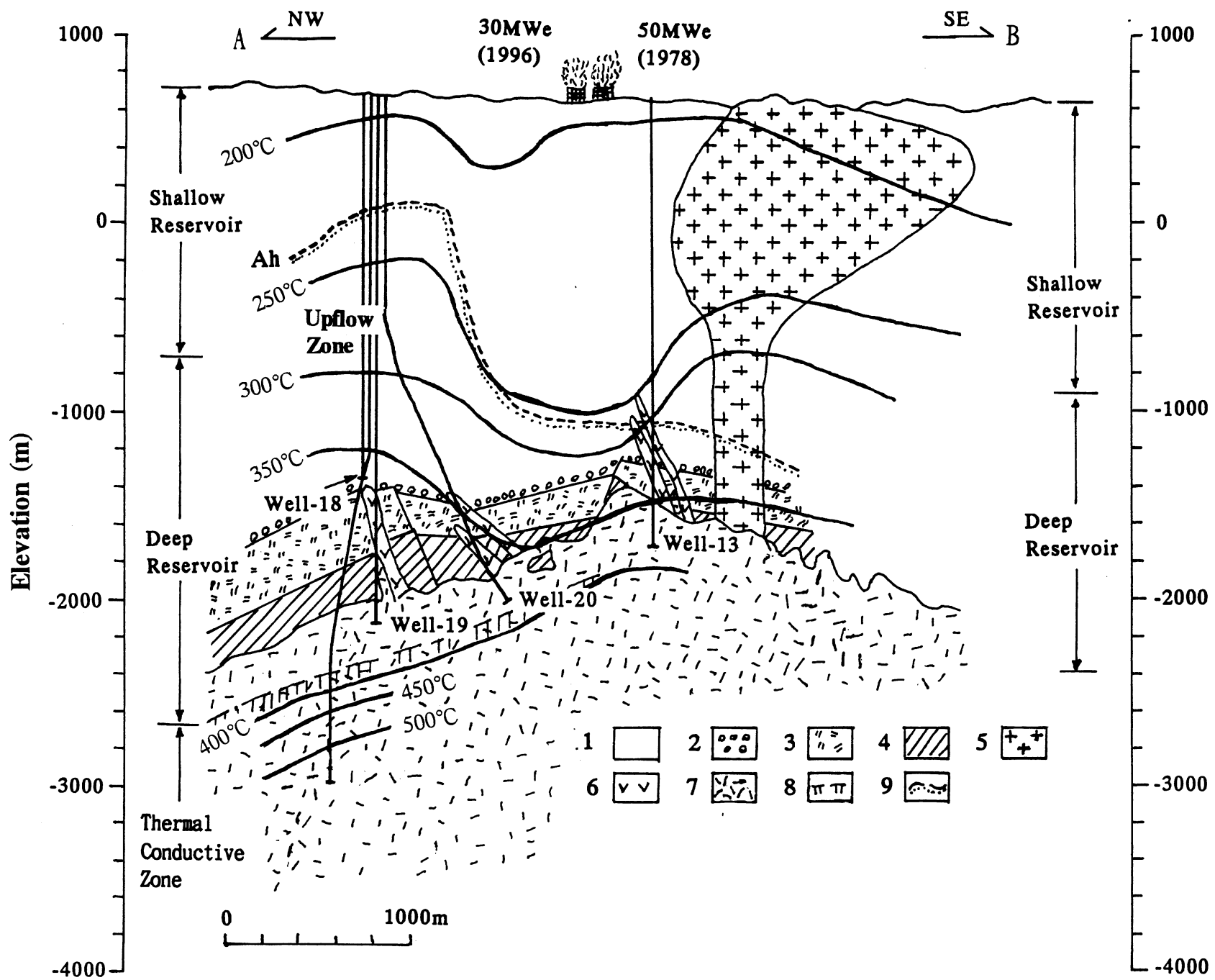

Figure 2. Schematic geologic cross section of the Kakkonda geothermal field (modified from Doi et al., 1998).

The figure is a section along line A-B in Figure 1. The isotherms were determined from static borehole temperature measurements of many wells drilled in the field. 1, Yamatsuda, Takinoue-onsen and Kunimitoge Formations; 2, Basal conglomerate in the Kunimitoge Formation; 3, Obonai Formation; 4, Pre-Tertiary formations; 5, Torigoenotaki dacite intrusion; 6, Old intrusions; 7, Kakkonda granite; 8, Boundary of permeability between marginal granite and less permeable inner granite; 9, Upper limit of anhydrite.

Chemical compositions of steam and hot water discharged from wells are shown in Table 1 (Nakamura and Sumi, 1981; JMC, unpublished data). The discharges from six wells except for Well-4 and Well-75 were collected at the initial stage of development of the Kakkonda geothermal field. The non-condensable gases in steam range from 0.02 to 0.09 vol.\% of the total discharge: the major gas (other than water vapor) is $\mathrm{CO}_{2}$ (49.6 to 73.6 vol.\%) with subordinate amount of $\mathrm{H}_{2} \mathrm{~S}$ (14.3 to 33.8 vol.\%). The hot waters are of $\mathrm{Na}-\mathrm{Cl}$ type with low salinity and alkaline of $\mathrm{pH} 8.39$ to 9.06 at room temperature.

\section{Sampling and Experimental Procedures}

The study involves a detailed examination in cores, cuttings and ejectas from Well-4. The abundant cuttings at $5 \mathrm{~m}$ intervals and only three cores $(900,1000$ and $1300 \mathrm{~m}$ depths) were prepared for this study. The cuttings range from 0.1 to $0.5 \mathrm{~cm}$ in diameter at above $1320 \mathrm{~m}$ depth, and have a very fine-grained size at below the depth. The ejectas of about $1 \mathrm{~kg}$ were collected when large amounts of the crystalline chips were fortunately produced with steam and hot water from the well at the initial opening after well completion.

The alteration mineralogy of these samples was studied using binocular and petrographic microscopes, 
Table 1. Chemical compositions of steams and hot waters discharged from wells at the Kakkonda geothermal field

\begin{tabular}{|c|c|c|c|c|c|c|c|c|}
\hline $\begin{array}{l}\text { Well } \\
\text { Sampling date }\end{array}$ & $\begin{array}{c}\text { Well-12*1 } \\
76.5 .24\end{array}$ & $\begin{array}{l}\text { Well-62 }{ }^{* 1} \\
76.5 .31\end{array}$ & $\begin{array}{l}\text { Well-71 }{ }^{* 1} \\
75.10 .11 \\
\end{array}$ & $\begin{array}{c}\text { Well-72*1 } \\
75.4 .30 \\
\end{array}$ & $\begin{array}{l}\text { Well-32 }{ }^{* 1} \\
76.3 .15 \\
\end{array}$ & $\begin{array}{l}\text { Well-41 } \\
74.11 .27 \\
\end{array}$ & $\begin{array}{l}\text { Well-4 } \\
84.7 .4 \\
\end{array}$ & $\begin{array}{l}\text { Well-75 } \\
81.10 .18 \\
\end{array}$ \\
\hline \multicolumn{9}{|l|}{ Steam phase } \\
\hline Pressure of steam sep., $\mathrm{kg} / \mathrm{cm}^{2} \mathrm{G}$ & 7.1 & 9.0 & 5.6 & 6.3 & 10.4 & 5.0 & & 6.0 \\
\hline Gas, vol\% & 0.070 & 0.084 & 0.044 & 0.038 & 0.021 & 0.087 & & 0.02 \\
\hline $\mathrm{CO}_{2}, \%$ & 70.9 & 62.4 & 58.2 & 49.6 & 55.1 & 73.6 & & 55.0 \\
\hline $\mathrm{H}_{2} \mathrm{~S}, \%$ & 14.3 & 25.2 & 28.6 & 33.8 & 33.1 & 18.3 & & 28.5 \\
\hline $\mathrm{H}_{2}, \%$ & 8.8 & 9.7 & 3.8 & 8.3 & 5.3 & 1.1 & & 13.4 \\
\hline $\mathrm{N}_{2}, \%$ & 4.2 & 2.0 & 7.3 & 5.6 & 6.0 & 5.2 & & 2.7 \\
\hline $\mathrm{CH}_{4}, \%$ & 1.8 & 0.8 & 2.1 & 2.7 & 0.5 & 1.8 & & 0.4 \\
\hline \multicolumn{9}{|l|}{ Liquid phase } \\
\hline $\mathrm{pH}$ & 9.06 & 9.05 & 8.99 & 8.80 & 8.95 & 8.95 & 8.39 & 8.40 \\
\hline $\mathrm{T}-\mathrm{CO}_{2}, \mathrm{mg} / \mathrm{l}$ & 19.6 & 6.7 & $\operatorname{Tr}$ & 20.4 & 36.6 & 20.4 & 15.8 & $<0.1$ \\
\hline $\mathrm{Cl}, \mathrm{mg} / \mathrm{l}$ & 629.2 & 623.8 & 618.4 & 654.0 & 606.5 & 674.2 & 1100 & 1070 \\
\hline $\mathrm{SO}_{4}, \mathrm{mg} / \mathrm{l}$ & 69.5 & 67.1 & 66.2 & 65.4 & 73.3 & 107.4 & 98.3 & 81.1 \\
\hline $\mathrm{Na}, \mathrm{mg} / \mathrm{l}$ & 429.0 & 443.0 & 471.0 & 460.0 & 475.0 & 492.0 & 706 & 650 \\
\hline $\mathrm{K}, \mathrm{mg} / \mathrm{l}$ & 59.0 & 59.0 & 62.6 & 55.0 & 61.0 & 63.0 & 84.6 & 79 \\
\hline $\mathrm{Ca}, \mathrm{mg} / 1$ & 7.74 & 8.49 & 10.1 & 8.26 & 8.30 & 10.9 & 24.1 & 17.3 \\
\hline $\mathrm{Mg}, \mathrm{mg} / 1$ & 0.01 & 0.01 & 0.02 & $\operatorname{tr}$ & $\operatorname{tr}$ & 0.34 & 0.01 & $<0.01$ \\
\hline $\mathrm{SiO}_{2}, \mathrm{mg} / 1$ & 551.0 & 571.0 & 515.0 & 558.0 & 572.0 & 732.0 & 489 & 567 \\
\hline $\mathrm{Fe}, \mathrm{mg} / \mathrm{l}$ & 0.125 & 0.407 & 0.08 & 0.03 & 0.36 & 1.35 & 0.19 & 0.19 \\
\hline $\mathrm{Al}, \mathrm{mg} / \mathrm{l}$ & 0.629 & 0.119 & 1.10 & 0.33 & 0.05 & 2.65 & 0.38 & 0.61 \\
\hline $\mathrm{H}_{2} \mathrm{~S}, \mathrm{mg} / \mathrm{l}$ & 1.7 & 6.06 & 2.0 & 0.9 & 1.31 & $\operatorname{tr}$ & 3.2 & $<0.1$ \\
\hline \multicolumn{9}{|l|}{ Present reservoir fluid } \\
\hline Temperature $\left(\mathrm{T}_{\mathrm{QZ}}\right),{ }^{\circ} \mathrm{C}$ & 233 & 236 & 229 & 234 & 236 & 255 & 225 & 236 \\
\hline
\end{tabular}

${ }^{* 1}$ Data sources are from Nakamura and Sumi (1981). The hot water was collected at atmospheric pressure. The temperature of the present reservoir fluid (Tqz) was calculated using quartz geothermometer with adiabatic cooling (Truesdall, 1976). Abbreviation: tr, Trace.

and XRD. Besides, the chemical analyses of the hydrothermal minerals in the ejectas were performed by a Hitachi scanning electronprobe microanalyzer (X650S) located at Institute for Advanced Material Processing, Tohoku University, and correction factors for analysis are those of Bence and Albee (1968). Heating experiments were carried out in a silicon oil-filled cell by a handmade heating-freezing stage mounted on an Olympus biological microscope equipped with a $40 \times$ ultra-long working distance objective lens. All heating measurements were performed twice to verify reproducibility and check for leakage. Successive calibration runs using metals with known melting points suggest that the accuracy of the measurements of homogenization temperature is within $\pm 1^{\circ} \mathrm{C}$.

Calculation of activities of chemical species in the present reservoir fluid from production wells was carried out using the composition of hot water and steam from the wells (Table 1) by the method of Arnorsson et al. (1982). The steam sample was not collected from Well-4 at the initial production test. Thus we indirectly estimated the composition of the present reservoir fluid from the well using the compositions of both hot water from the well and steam discharged from adjacent Well-75, which produced the fluid through the same fracture as Well-4.

\section{Results and Discussion}

\section{Drilling data and stratigraphic setting}

Well head of Well-4 is located to about $600 \mathrm{~m}$ northern part of the Kakkonda geothermal power station (Fig. 1). The well was completed to a depth of $1448 \mathrm{~m}$ (last casing of $1000 \mathrm{~m}$ depth). The stratigraphic sequence of the well drilled near the uppermost western margin of the Matsuzawa tonalite includes the Miocene formations such as the Yamatsuda Formation (0 to $317 \mathrm{~m}$ depth), the Takinoue-onsen Formation (317 to $657 \mathrm{~m}$ depth), and the underlying thick Kunimitoge Formation (657 to $1448 \mathrm{~m}$ depth) (Fig. 3; Doi et al., 1995). The Yamatsuda Formation is composed of siltstone, pumiceous tuff and dacitic tuff, and the Takinoue-onsen Formation is composed of shale, dacitic tuff and pumiceous tuff. The Kunimitoge Formation as a shallow reservoir is composed of a thick dacitic tuff with thin andesite 


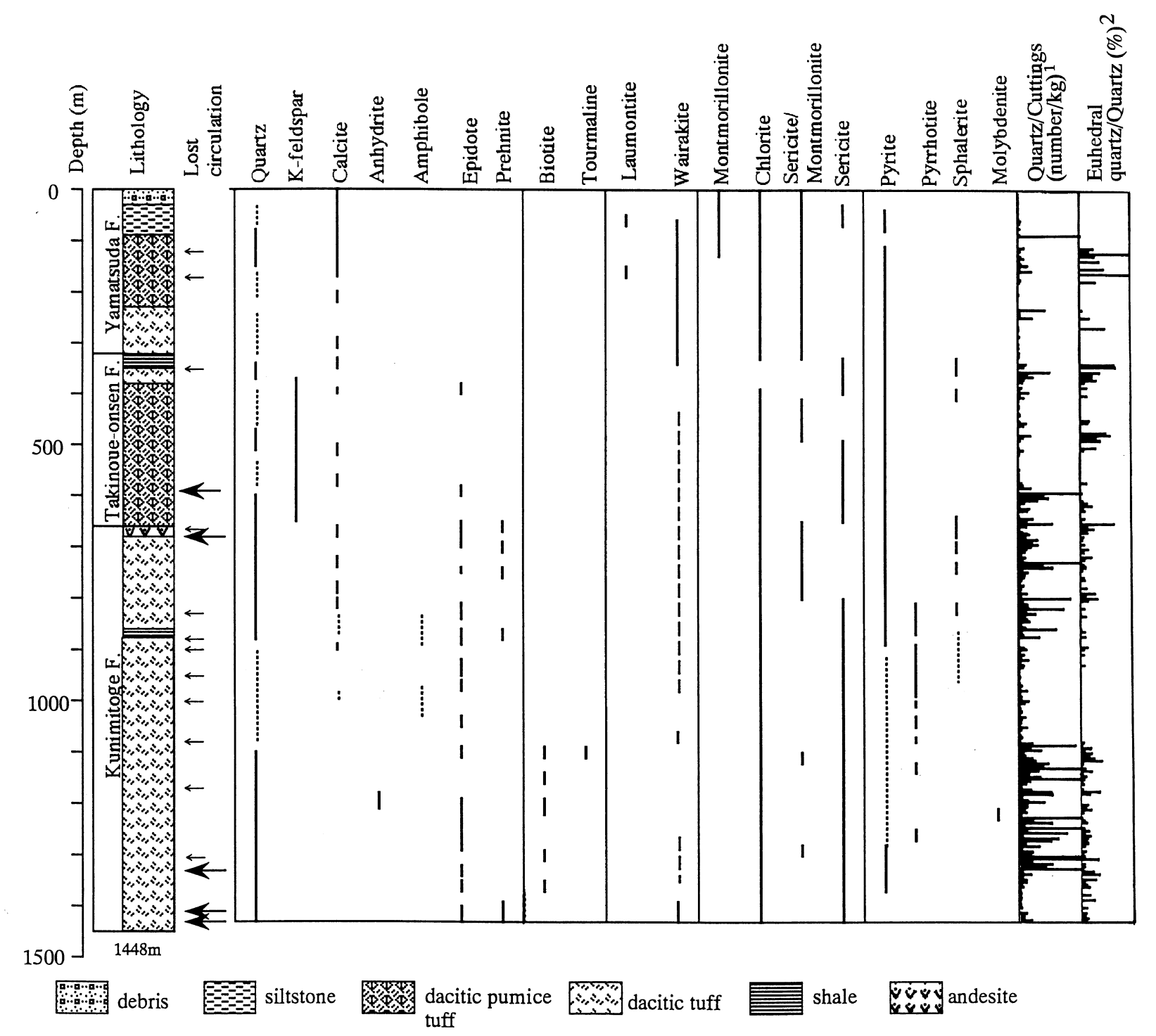

Figure 3. Distribution of alteration minerals from Well-4 in the Kakkonda geothermal field.

${ }^{1}$ number of vein quartz/1 kg of cuttings.

${ }^{2}$ number of euhedral quartz/number of vein quartz $\times 100 \%$.

Lost circulation data are from Doi et al. (1995). Long and short arrows indicate large and small circulation losses, respectively.

lava and black shale. The dacitic tuff and black shale are strongly silicified at below $862 \mathrm{~m}$ depth, resulting from a magmatic activity related to the Matsuzawa tonalite. Large circulation losses were encountered at the three zones as follows: dacitic pumice tuff in the lower part of the Takinoue-onsen Formation, the uppermost altered andesite and the silicified dacitic tuff (below $1300 \mathrm{~m}$ ) in the Kunimitoge Formation. In these zones, the lost circulation zone near the altered andesite in the Kunimitoge Formation has been utilizing for reinjection at the Kakkonda field. The dynamic borehole temperature logging measured after well completion indicates that a feed point of Well-4 is at 1428 $\mathrm{m}$ depth (JMC, unpublished data).

\section{Alteration mineralogy}

Alteration near Well-4 is related to two major events: contact metamorphism of biotite-rich hornfels resulting from intrusion of the Matsuzawa tonalite, and hydrothermal alteration resulting from a hydrothermal activity developed after emplacement of the Quaternary intrusions such as the Matsuzawa tonalite and the Kakkonda granite.

Figure 3 shows the distribution of the alteration minerals with depth in the well. Metamorphic biotite has been identified at below $1100 \mathrm{~m}$ depth. Quartz occurs abundantly as transparent or translucent fracturefilling minerals. The amounts of vein quartz and euhe- 
dral quartz in the cuttings from each depth are also shown in Figure 3. Unfortunately, the data from below $1320 \mathrm{~m}$ depth may not keep the correct value because of fine-grained size of the cuttings. The vein quartz increases in quantity at two depth intervals of 600 to 870 $\mathrm{m}$ and below $1070 \mathrm{~m}$. Potassium feldspar with shape of adularia under a SEM (Honda et al., 1982) occurs at depths between 350 and $650 \mathrm{~m}$. It was formed after emplacement of the Kakkonda granite as suggested by $\mathrm{K}-\mathrm{Ar}$ age of $0.2 \pm 0.1 \mathrm{Ma}$ (Koshiya et al., 1993). Calcite occurs widely and sparsely as hydrothermal vein mineral or partial replacement one of plagioclase at above $1050 \mathrm{~m}$ depth.

Prehnite is commonly associated with quartz and wairakite. It is noteworthy that the mineral occurs at near the large lost circulation zones: reinjection zone between 657 and $850 \mathrm{~m}$, and production zone below $1380 \mathrm{~m}$ depth. Hydrothermal epidote occurs dispersively at below $400 \mathrm{~m}$, and in particular with prehnite at below $1418 \mathrm{~m}$. In two zeolites, laumontite occurs scarcely in minor amounts at near the surface above 180 $\mathrm{m}$ depth, whereas wairakite is mostly found in abundance at depths between 80 and $300 \mathrm{~m}$, but scarce at below $300 \mathrm{~m}$ depth.

Pyrite commonly occurs as fracture filling or dissemination. A small quantity of hydrothermal pyrrhotite occurs usually with quartz at depths between 800 and $1200 \mathrm{~m}$. We could not determine its composition conveniently by the position of the $\mathrm{d}_{102}$ peak (Toulmin and Barton, 1964) because of its minor amount. However, pyrrhotite has a monoclinic form from its magnetic property. Comparison between the upper stability limit of monoclinic pyrrhotite of $254^{\circ} \mathrm{C}$ (Kissin, 1974) and the measured static borehole temperatures (SBT) of 217 to $237^{\circ} \mathrm{C}$ at its distribution zone (Fig. 4) indicates that the temperature of the reservoir fluid has decreased about 20 to $40^{\circ} \mathrm{C}$ in maximum since formation of monoclinic one.

\section{Fluid inclusion microthermometry and borehole tem- perature measurement}

Microthermometry was performed on hydrothermal quartz cuttings from 23 different depths in Well-4. Fluid inclusions in size mostly less than $10 \mu \mathrm{m}$ are only liquid-rich inclusions without containing vapor-rich and polyphase inclusions, suggesting that boiling did not occur after formation of quartz. Figure 4 shows the distribution of the homogenization temperatures (Th) for the liquid-rich inclusions with depth. After increasing abruptly from 60 to $360 \mathrm{~m}$ depth, Th values range from 225 to $300^{\circ} \mathrm{C}$ at depth below $360 \mathrm{~m}$. We could not

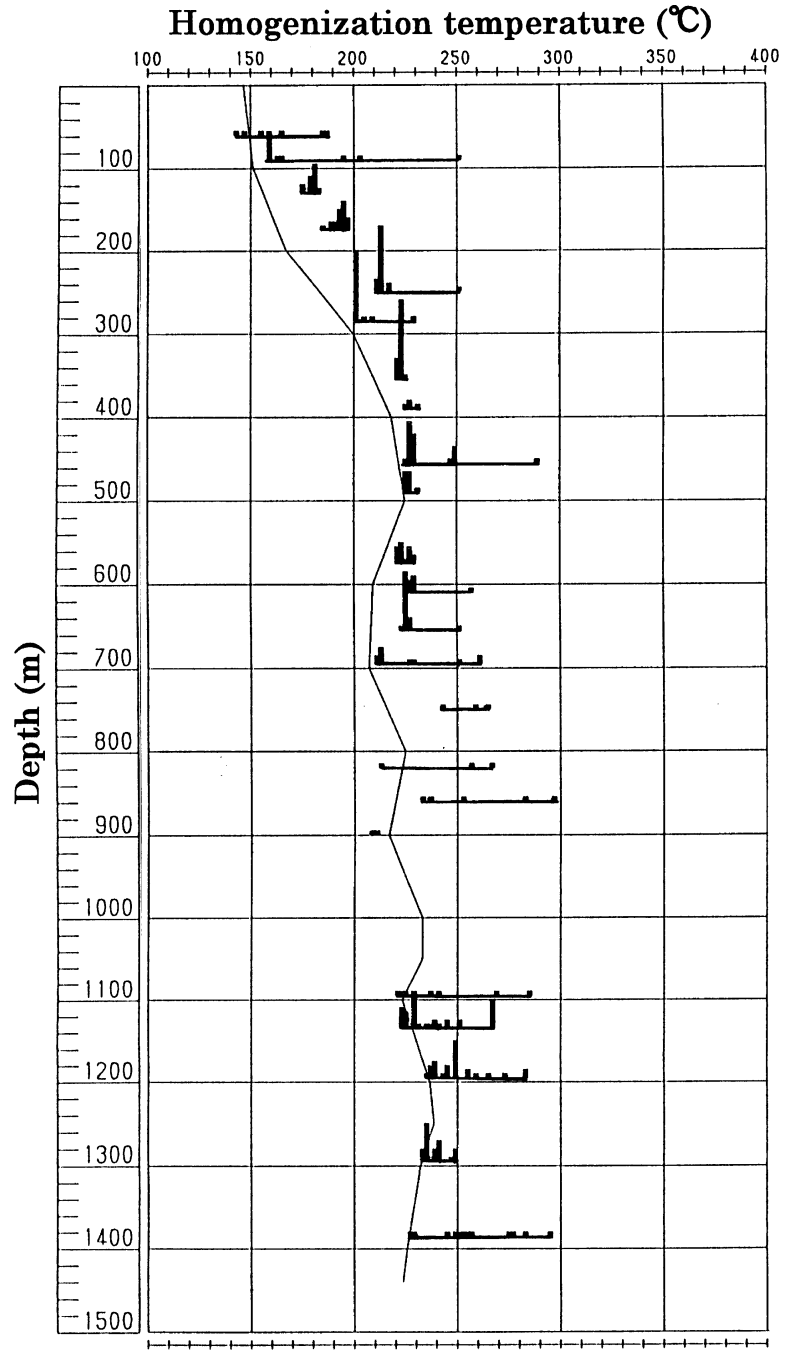

Figure 4. Distribution of homogenization temperatures for liquid-rich inclusions in quartz and measured static borehole temperature profile with depth in Well-4.

Solid line indicates the static borehole temperature measured about one year after well completion.

measure Th of fluid inclusion in quartz of the ejectas because of its tiny crystal.

On the other hand, the SBT values indicate that the formation temperatures at depth below $400 \mathrm{~m}$ range from 210 to $240^{\circ} \mathrm{C}$ (Fig. 4). Comparison of the SBT and the Th values reveals that the reservoir temperature has cooled down since formation of quartz. The SBT value of $224^{\circ} \mathrm{C}$ at the feed point is almost equal to the minimum $\mathrm{Th}$ value of $228^{\circ} \mathrm{C}$ for liquid-rich inclusions in quartz from $1390 \mathrm{~m}$ depth. The reservoir fluid temperature of $232^{\circ} \mathrm{C}$ measured under dynamic conditions (JMS, unpublished data) is slightly higher than the quartz geothermometer of $225^{\circ} \mathrm{C}$ at the feed point as mentioned later, suggesting that the present reservoir fluid flows into the well through the productive fracture 
from a slightly higher temperature area.

\section{Mineral paragenesis, composition and origin of ejecta}

Chips ejected at the initial opening of Well-4 are round in shape because of grinding against well wall with flowing upward in the well (Fig. 5A). Based on the calc-silicate mineral assemblage, most of the ejectas can be largely divided into white and pale green types. Those contain many cavities (maximum $3 \mathrm{~mm}$ size in diameter) where euhedral quartz with $0.2 \times 0.8 \mathrm{~mm}$ in average size has grown (Fig. 5B). The white ejectas consist mainly of euhedral quartz and calc-silicate minerals in the system $\mathrm{CaO}-\mathrm{Al}_{2} \mathrm{O}_{3}-\mathrm{SiO}_{2}-\mathrm{H}_{2} \mathrm{O}$ such as prehnite and wairakite without epidote (Fig. 5C). Surface of some euhedral quartz has partly dissolved. Wairakite was replaced partly by radial aggregates of fibrous thomsonite (?). The microscopic texture shows that the cavities had been gradually sealed as these minerals had grown. On the other hand, the pale green ejectas consist mainly of quartz, chlorite and the calcsilicate minerals in the system $\mathrm{CaO}-\mathrm{Al}_{2} \mathrm{O}_{3}\left(-\mathrm{Fe}_{2} \mathrm{O}_{3}\right)$ $\mathrm{SiO}_{2}-\mathrm{H}_{2} \mathrm{O}$ such as prismatic green epidote and prehnite without wairakite (Fig. 5D), but some of the ejectas contain small amounts of pyrite, rutile, sphene and apatite. Texture of the calc-silicate minerals in the pale green ejectas under the microscope shows that epidote was the first mineral to precipitate, followed by prehnite.

Compositions of epidote and prehnite in some of the pale green ejectas and wairakite in the white ejecta determined using the electron microprobe are shown in Table 2. The major nonstoichiometry of epidote solid solution results from the substitution of $\mathrm{Fe}^{3+}$ and $\mathrm{Al}^{3+}$ in the octahedral sites. The $\mathrm{Fe}^{3+} /\left(\mathrm{Fe}^{3+}+\mathrm{Al}^{3+}\right)$ contents of epidote range from pistacite $\left[\mathrm{Ca}_{2} \mathrm{Fe}_{3} \mathrm{Si}_{3} \mathrm{O}_{12}(\mathrm{OH})\right]$ mole fraction of 0.22 to 0.25 . Iron was not detected in measured two prehnite grains which coexists intimately with epidote, but some prehnite grains contain small amounts of $\mathrm{Mn}$ or $\mathrm{Mg}$. Wairakite contains $3.59 \mathrm{wt} \%$ of $\mathrm{Na}_{2} \mathrm{O}$.
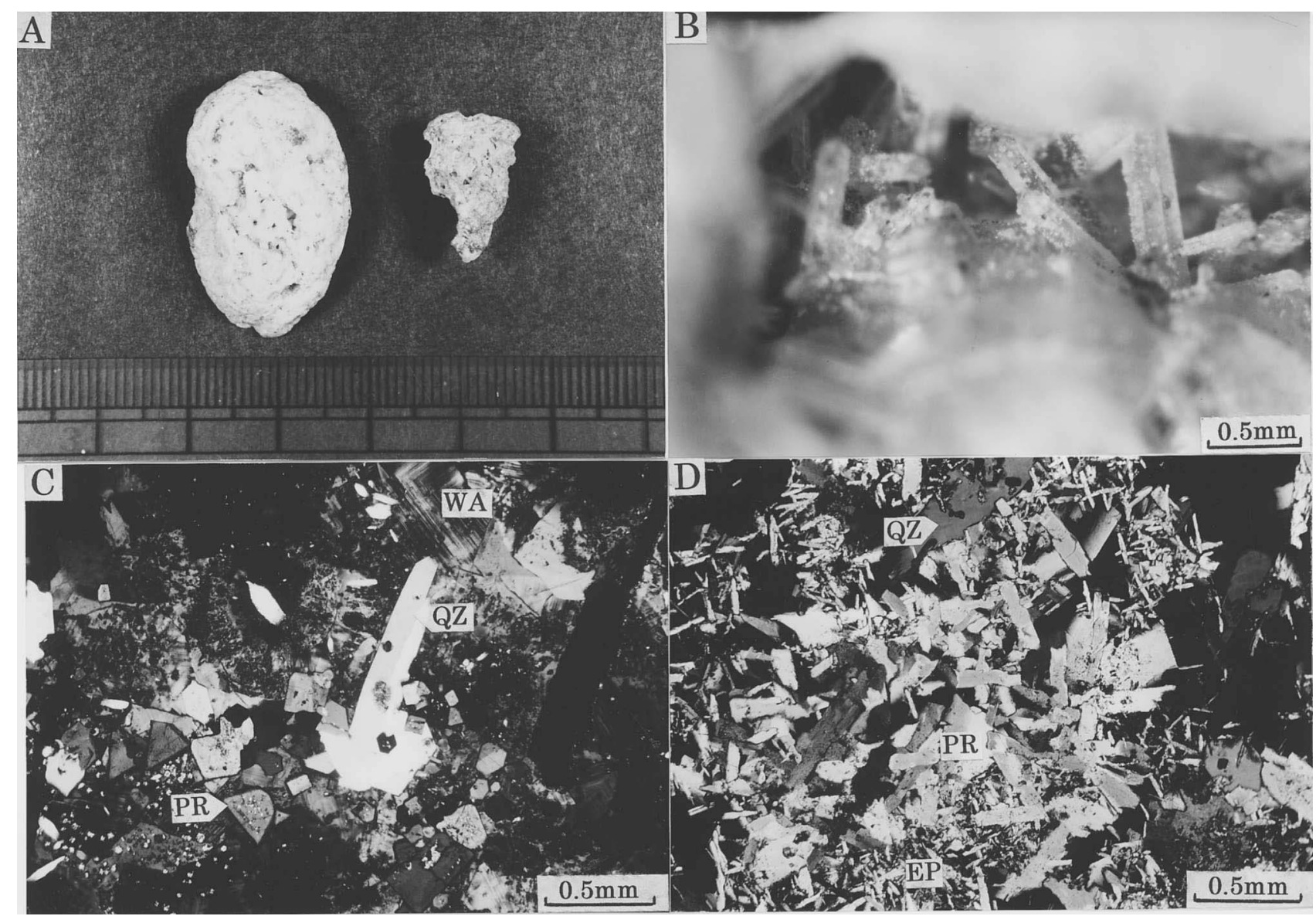

Figure 5. Photographs of ejectas from Well-4.

(A) White (left) and pale green (right) ejectas. (B) Euhedral quartz growing in druse of white ejecta. (C) Texture of euhedral quartz, prehnite and wairakite in white ejecta. Cross polarized light. (D) Prehnite occurring with epidote in pale green ejecta. Cross polarized light. PR, prehnite; QZ, quartz; WA, wairakite; EP, epidote. 
Table 2. Microprobe analyses of epidote, prehnite and wairakite in the ejectas from Well-4 in the Kakkonda field

\begin{tabular}{|c|c|c|c|c|c|c|c|}
\hline & \multicolumn{3}{|c|}{ epidote } & \multicolumn{3}{|c|}{ prehnite } & \multirow[t]{2}{*}{ wairakite } \\
\hline & 1 & 2 & 3 & 1 & 2 & 3 & \\
\hline $\mathrm{SiO}_{2}$ & 38.33 & 38.45 & 38.42 & 43.51 & 43.68 & 44.23 & 55.32 \\
\hline $\mathrm{TiO}_{2}$ & 0.00 & 0.00 & 0.00 & 0.00 & 0.00 & 0.00 & 0.00 \\
\hline $\mathrm{Al}_{2} \mathrm{O}_{3}$ & 23.11 & 24.61 & 24.50 & 23.19 & 25.02 & 23.98 & 20.88 \\
\hline $\mathrm{Fe}_{2} \mathrm{O}_{3} *$ & 11.95 & 11.04 & 10.63 & 0.00 & 0.00 & 0.00 & 0.00 \\
\hline $\mathrm{MnO}$ & 0.00 & 0.00 & 0.00 & 0.68 & 0.00 & 0.00 & 0.00 \\
\hline $\mathrm{MgO}$ & 0.88 & 0.00 & 1.78 & 0.00 & 0.00 & 0.92 & 0.00 \\
\hline $\mathrm{CaO}$ & 24.04 & 23.96 & 23.34 & 27.10 & 27.39 & 26.46 & 8.72 \\
\hline $\mathrm{Na}_{2} \mathrm{O}$ & 0.00 & 0.00 & 0.00 & 0.00 & 0.00 & 0.00 & 3.59 \\
\hline \multirow[t]{2}{*}{ total } & 98.31 & 98.06 & 98.67 & 94.48 & 96.09 & 95.59 & 88.51 \\
\hline & 12 & oxygen & atoms & 10 & oxygen & atoms & 12 oxygen atoms \\
\hline $\mathrm{Si}$ & 2.91 & 2.91 & 2.89 & 2.76 & 2.71 & 2.75 & 4.14 \\
\hline $\mathrm{Ti}$ & 0.00 & 0.00 & 0.00 & 0.00 & 0.00 & 0.00 & 0.00 \\
\hline $\mathrm{Al}$ & 2.07 & 2.20 & 2.17 & 1.73 & 1.83 & 1.76 & 1.84 \\
\hline $\mathrm{Fe}$ & 0.68 & 0.63 & 0.60 & 0.00 & 0.00 & 0.00 & 0.00 \\
\hline $\mathrm{Mn}$ & 0.00 & 0.00 & 0.00 & 0.04 & 0.00 & 0.00 & 0.00 \\
\hline $\mathrm{Mg}$ & 0.10 & 0.00 & 0.20 & 0.00 & 0.00 & 0.09 & 0.00 \\
\hline $\mathrm{Ca}$ & 1.96 & 1.94 & 1.88 & 1.84 & 1.82 & 1.77 & 0.70 \\
\hline $\mathrm{Na}$ & 0.00 & 0.00 & 0.00 & 0.00 & 0.00 & 0.00 & 0.52 \\
\hline$\overline{\mathrm{ps}}$ & 25 & 22 & 22 & $\mathrm{Xps}=$ & $3^{3+} /(\mathrm{F}$ & $\left.+\mathrm{Al}^{3+}\right)$ & \\
\hline
\end{tabular}

*all $\mathrm{Fe}$ as $\mathrm{Fe}_{2} \mathrm{O}_{3}$. Xps indicates a pistacite mole fraction.

The hydrothermal mineral assemblage of the ejectas is very similar to that of cuttings from the feed point of Well-4. Therefore, it is deduced that the ejectas are derived from drusy minerals precipitated in a productive open fracture developed in a strongly silicified dacitic fine tuff at $1428 \mathrm{~m}$ depth.

The same calc-silicate mineral assemblage as the ejectas from Well-4 in the Kakkonda field was found inside casing of a well as a scale at the Ngatamariki geothermal field, New Zealand (Browne et al., 1989). Browne et al. (1989) showed that the scale consists of euhedral crystals of wairakite, prehnite and Fe-rich epidote, plus rare quartz and pyrite, and wairakite grows at the approximate minimum growth rate of $190 \mu \mathrm{m}^{3}$ per day from the present reservoir fluid.

\section{Present reservoir fluid - calc-silicate mineral equili- bria}

Based on our microscopic observation of the ejectas, the present reservoir fluid has been flowing within the productive fracture partly self-sealed with precipitation of euhedral quartz and calc-silicate minerals. According to Muramatsu and Komatsu (1996), the euhedral quartz occurs in most productive fractures of the Kakkonda field. Quartz geothermometer is in agreement with the SBT value in shallow wells (Akeno, 1978), suggest- ing that the present reservoir fluid is approximately saturated with respect to quartz in the shallow reservoir of the field. Thus the euhedral quartz is an indicator of the productive fractures. This assumption is supported by the oxygen isotopic difference between vein quartz in fullfilled fracture and euhedral quartz in unfilled open fracture (Kato et al., 1997).

The data of the quartz geothermometer, SBT and minimum Th values shows that the present reservoir fluid from Well-4 has a temperature of approximately $225^{\circ} \mathrm{C}$ (Table 1). Figure 6 shows the phase relation in the system $\mathrm{CaO}-\mathrm{Al}_{2} \mathrm{O}_{3}\left(-\mathrm{Fe}_{2} \mathrm{O}_{3}\right)-\mathrm{SiO}_{2}-\mathrm{H}_{2} \mathrm{O}$ at $225^{\circ} \mathrm{C}$ as a function of $\log \left(\mathrm{a}_{\mathrm{Ca}^{2+}}{ }^{2+} / \mathrm{a}^{2}{ }_{\mathrm{H}}{ }^{+}\right)$and $\log \left(\mathrm{a}_{\mathrm{SiO}_{2}(\mathrm{aq})}\right)$, where the fluid is saturated with quartz and has temperature for pressures corresponding to liquid-vapor equilibrium for $\mathrm{H}_{2} \mathrm{O}$. The epidote has a pistacite mole fraction of 0.22 to 0.25 as mentioned previously, and these values converted to activity for clinozoisite ( $\mathrm{a}_{\text {clinozoisite }}$ ) of 0.3 and epidote $\left(\mathrm{a}_{\text {epidote }}\right)$ of 0.7 (Bird and Helgeson, 1980). From the deduced fluid composition (open star) for Well-4 in this figure, it is suggested that the present reservoir fluid is in equilibrium with prehnite as well as quartz. Considering our observation result that prehnite is present as later stage product of the calc-silicate minerals in the ejectas from the feed point of the well as mentioned previously, prehnite must be partly precipitated from the recent reservoir fluid. 


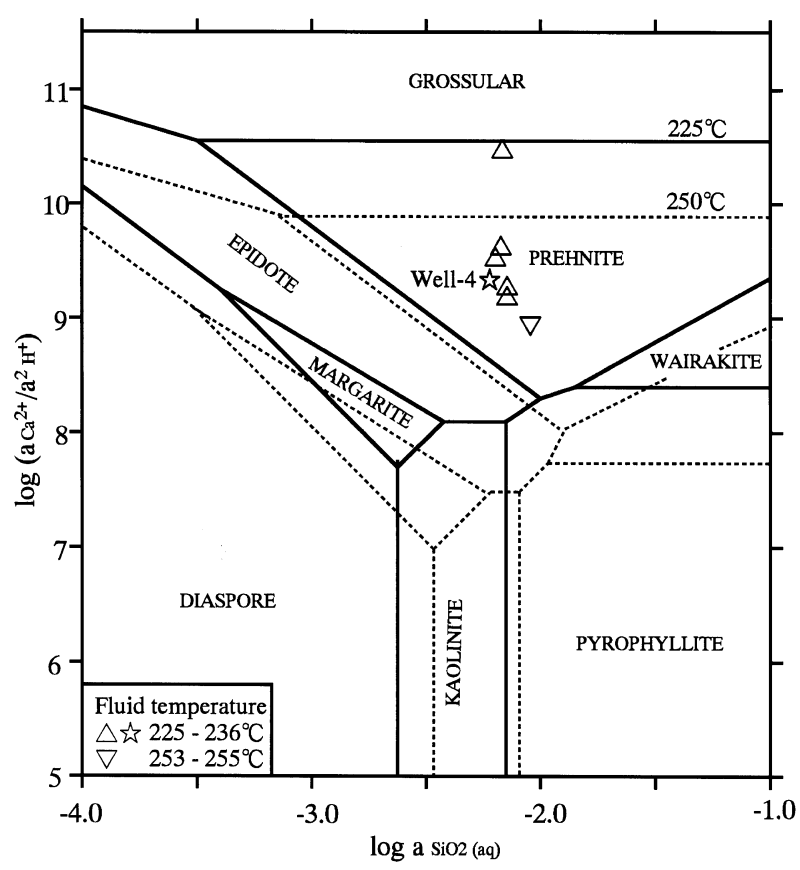

Figure 6. Phase relation in the system $\mathrm{CaO}-\mathrm{Al}_{2} \mathrm{O}_{3}\left(-\mathrm{Fe}_{2} \mathrm{O}_{3}\right)-$ $\mathrm{SiO}_{2}-\mathrm{H}_{2} \mathrm{O}$ in the presence of quartz at 225 and $250^{\circ} \mathrm{C}$, and saturated water vapor pressure, as a function of $\log \left(\mathrm{a}_{\mathrm{Ca}^{2+}} /\right.$ $\left.\mathrm{a}_{\mathrm{H}}^{2}{ }^{+}\right)$and $\log \left(\mathrm{a}_{\mathrm{SiO}_{2}(\mathrm{aq})}\right)$ in the aqueous phase.

The stability areas of the various minerals correspond to those of the pure end member phases except for epidote which was assumed to contain 22 mole\% of pistacite. Open star and open triangles plot deduced fluid compositions for Well-4 and the other shallow wells, respectively.

Figure 7 shows the phase relation in the system $\mathrm{CaO}-\mathrm{Al}_{2} \mathrm{O}_{3}\left(-\mathrm{Fe}_{2} \mathrm{O}_{3}\right)-\mathrm{SiO}_{2}-\mathrm{H}_{2} \mathrm{O}$ in equilibrium with calcite and chalcedony as a function of $\log \mathrm{f}_{\mathrm{CO}_{2}}$ and temperature (Giggenbach, 1997). Chalcedony is supersaturated about $10 \%$ with respect to quartz (Chiba, 1991). $\mathrm{P}_{\mathrm{CO}_{2}}$ is taken to be equal to $\mathrm{f}_{\mathrm{CO}_{2}}$. The figure suggests that the present reservoir fluid (open star) from Well-4 is in equilibrium with prehnite and calcite as well as chalcedony. It is inconsistent with no occurrence of calcite in cutting from the feed point of the well, suggesting that the present reservoir fluid flows into the well through the productive fracture from calcite-bearing reservoir rock whose temperature is slightly higher than the feed point.

Figures 6 and 7 also contain the deduced reservoir fluid compositions (open triangle) for six shallow production wells at the initial stage of development of the Kakkonda field. The present reservoir fluids calculated by the quartz geothermometer have slightly wide temperature ranges of 229 to $255^{\circ} \mathrm{C}$ (Table 1). Then, Figure 6 shows the phase relation in the system $\mathrm{CaO}-\mathrm{Al}_{2} \mathrm{O}_{3}$ $\left(-\mathrm{Fe}_{2} \mathrm{O}_{3}\right)-\mathrm{SiO}_{2}-\mathrm{H}_{2} \mathrm{O}$ at $250^{\circ} \mathrm{C}$ in addition to $225^{\circ} \mathrm{C}$. It is apparent from these figures that the present reservoir

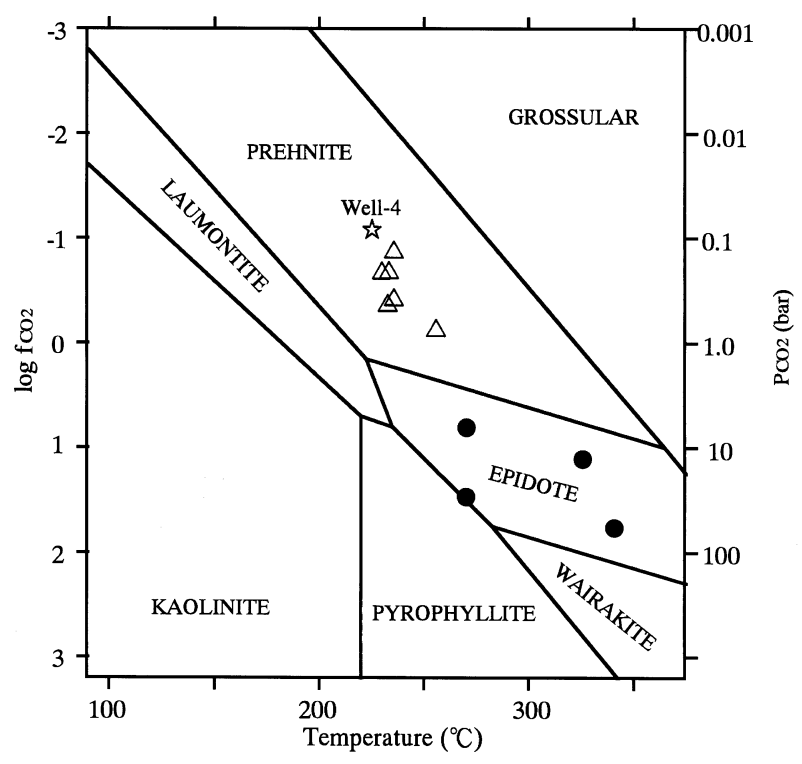

Figure 7. Phase relation in the system $\mathrm{CaO}-\mathrm{Al}_{2} \mathrm{O}_{3}\left(-\mathrm{Fe}_{2} \mathrm{O}_{3}\right)$ $\mathrm{SiO}_{2}-\mathrm{H}_{2} \mathrm{O}$ in equilibrium with calcite and chalcedony as a function of $\log \mathrm{f}_{\mathrm{CO}_{2}}$ and temperature (Giggenbach, 1997).

The stability areas of the various minerals correspond to those of the pure end member phases except for epidote which was assumed to contain 22 mole\% of pistacite. Prehnite and wairakite have extended stabilities that overprints portion of the epidote field in the system $\mathrm{CaO}-\mathrm{Al}_{2} \mathrm{O}_{3}-\mathrm{SiO}_{2}-\mathrm{H}_{2} \mathrm{O}$. Open star and open triangles plot deduced fluid compositions for Well-4 and the other shallow wells, respectively. Solid circles plot the gas analytical data of fluid inclusions in anhydrite (Muramatsu et al., 2000).

fluids from the wells are also in equilibrium with prehnite, quartz and calcite. As prehnite occurs at near the large lost circulation zones in Well-4 as mentioned previously, the mineral appears to be a good indicator of the productive fractures as an essential factor on the development of the shallow reservoir of the Kakkonda field.

\section{Fossil reservoir fluid - calc-silicate mineral equilibria}

Based on the relationship between distribution of prehnite (Fig. 3) and Th values for liquid-rich inclusions in quartz with depth in Well-4 (Fig. 4), the calc-silicate minerals such as epidote, prehnite and wairakite from deeper levels must have formed from the fossil reservoir fluid at temperatures of approximately 225 to $300^{\circ} \mathrm{C}$. Figure 7 shows the stability field for the calc-silicate mineral assemblages found in the ejectas. The genetic sequence of the calc-silicate minerals suggests that $\mathrm{Fe}$ content in the fossil reservoir fluid has been decreased with time. The figure represents only $\mathrm{Fe}$-rich fluid condition compatible with epidote in the system $\mathrm{CaO}^{-}$ $\mathrm{Al}_{2} \mathrm{O}_{3}\left(-\mathrm{Fe}_{2} \mathrm{O}_{3}\right)-\mathrm{SiO}_{2}-\mathrm{H}_{2} \mathrm{O}$. On the case of phase rela- 
tion in the system $\mathrm{CaO}-\mathrm{Al}_{2} \mathrm{O}_{3}-\mathrm{SiO}_{2}-\mathrm{H}_{2} \mathrm{O}$, prehnite and wairakite have extended stabilities that overprints portion of the epidote field. From the figure, it is suggested that the decreasing of temperature and $\mathrm{f}_{\mathrm{CO}_{2}}$ in the reservoir fluid with time has shifted the calc-silicate mineral stabilities from epidote or prehnite-wairakite to prehnite.

Anhydrite occurs as a representative hydrothermal mineral in the northwest upflow zone of the Kakkonda field (Kato and Doi, 1993). Most of them precipitated after emplacement of the Kakkonda granite. Muramatsu et al. (2000) analyzed the gas composition of secondary predominant liquid-rich inclusions in anhydrites from four different depths of Well-18 by a quadruple mass spectrometer. As shown in Fig. 7, the inclusion fluids (solid circle) are in equilibrium with epidote or prehnite-wairakite as well as quartz and calcite. According to Muramatsu et al. (2000), the $\mathrm{CO}_{2}$ content in the reservoir fluids has decreased from the inclusion trapping stage to the present, resulting from the degassing of $\mathrm{CO}_{2}$-rich reservoir fluid due to multi-step vapor separation. Therefore, the decreasing of temperature and $\mathrm{f}_{\mathrm{CO}_{2}}$ in the reservoir fluid from the epidote or the prehnite-wairakite stability stages to the prehnite stability stage may be also substantially attributed to this degassing process.

\section{Conclusions}

(1) The chips ejected at the initial opening of a shallow production well (Well-4) in the Kakkonda geothermal field consist mainly of euhedral quartz and calcsilicate minerals in the system $\mathrm{CaO}-\mathrm{Al}_{2} \mathrm{O}_{3}\left(-\mathrm{Fe}_{2} \mathrm{O}_{3}\right)$ $\mathrm{SiO}_{2}-\mathrm{H}_{2} \mathrm{O}$ such as prehnite, epidote (pistacite mole fraction of 0.22 to 0.25 ) and wairakite. The ejectas were derived from drusy minerals in a productive fracture where is connected to a feed point of the well.

(2) On the basis of thermodynamic analyses of the calc-silicate minerals-the present reservoir or inclusion fluids equilibrium, the present reservoir fluid maintains a state close to equilibrium with prehnite as well as quartz and calcite, whereas the fossil reservoir fluid is in equilibrium with epidote or prehnite-wairakite as well as quartz and calcite. The decreasing of temperature and $\mathrm{f}_{\mathrm{CO}_{2}}$ in the reservoir fluids has shifted the calcsilicate mineral stabilities from epidote or prehnitewairakite to prehnite. The process may result from the degassing of $\mathrm{CO}_{2}$-rich reservoir fluid.

(3) Prehnite is a good indicator of the productive fractures where are a path of the present reservoir fluid in the shallow reservoir of the Kakkonda field.

\section{Acknowledgements}

We wish to express thanks to Japan Metals and Chemicals Co., Ltd. and Tohoku Geothermal Energy Co., Ltd. for their permission to use unpublished logging and geochemical data of Well-4 and Well-75, and publish this paper. We also thank two anonymous reviewers for their constructive comments on this manuscript. This research was financially supported in part by a Grant-in-Aid for Scientific Research from the Ministry of Education, Science, Sports and Culture of Japan (No. 09651032).

\section{References}

Akeno, T. (1978) Geochemical survey in Takinoue geothermal field, Iwate Pref., Japan, using the ratios of methane to hydrogen in gases issued fumaroles and hotsprings. Chinetsu, 15, 75-85 (in Japanese with English abstract).

Arnorsson, S., Sigurdsson, S. and Svavarsson, H. (1982) The chemistry of geothermal waters in Iceland. I. Calculation of aqueous speciation from $0^{\circ}$ to $370^{\circ} \mathrm{C}$. Geochimica et Cosmochimica Acta, 46, 1513-1532.

Bence, T. and Albee, A. (1968) Empirical correction factors for the electron microanalysis of silicates and oxides. Journal of Geology, 76, 382-401.

Bird, D.K., and Helgeson, H.C. (1980) Chemical interaction of aqueous solutions with epidote-feldspar mineral assemblages in geologic systems. I. Thermodynamic analysis of phase relations in the system $\mathrm{CaO}-\mathrm{FeO}-\mathrm{Fe}_{2} \mathrm{O}_{3}-\mathrm{Al}_{2} \mathrm{O}_{3}-$ $\mathrm{SiO}_{2}-\mathrm{H}_{2} \mathrm{O}-\mathrm{CO}_{2}$. American Journal of Science, 280, 907941.

Browne, P, R.L., Courtney, S.F. and Wood, C.P. (1989) Formation rates of calc-silicate minerals deposited inside drillhole casing, Ngatamariki geothermal field. American Mineralogist, 74, 759-763.

Chiba, H. (1991) Attainment of solution and gas equilibrium in Japanese geothermal systems. Geochemical Journal, $25,335-355$.

Doi, N., Kato, O., Kanisawa, S. and Ishikawa, K. (1995) Neo-tectonic fracturing after emplacement of Quaternary granitic pluton in the Kakkonda geothermal field, Japan. Geothermal Resources Council Transactions, 19, 297-303.

Doi, N., Kudo, H., Takanohashi, M. and Niitsuma, H. (1988) AE measurement and fracture behavior during hydraulic fracturing in the Kakkonda geothermal field, Japan. Journal of the Geothermal Research Society of Japan, 10, 237-248 (in Japanese with English abstract).

Doi, N., Kato, O., Ikeuchi, K., Komatsu, R., Miyazaki, S.-I., Akaku, K. and Uchida, T. (1998) Genesis of the plutonic-hydrothermal system around Quaternary granite in the Kakkonda geothermal reservoir, Japan. Geothermics, 27, 663-690.

Giggenbach, W.F. (1997) The origin and evolution of fluids in magmatic-hydrothermal systems. In Geochemistry of Hydrothermal Ore Deposits, Third editions (Barnes, H.L., ed.) John Wiley, New York, 737-796.

Honda, S., Nagai, A and Chiba, Y. (1982) K-feldspar as an 
alteration mineral from the geothermal wells ER-2 and KC-5 at Kakkonda geothermal field. 1982 Annual Meeting Geothermal Research Society of Japan, Abstracts with Programs, 70 (in Japanese).

Kanisawa, S., Doi, N., Kato, O. and Ishikawa, K. (1994) Quaternary Kakkonda Granite underlying the Kakkonda geothermal field, Northeast Japan. Journal of Mineralogy, Petrology and Economic Geology, 89, 390-407 (in Japanese with English abstract).

Kato, O. and Doi, N. (1993) Neo-granite pluton and later hydrothermal alteration at the Kakkonda geothermal field, Japan. Proceedings of the 15 th New Zealand Geothermal Workshop 1993, 155-161.

Kato, O., Kasai, K. and Uchida, T. (1997) Distribution of oxygen isotopic ratios of reservoir rocks and vein quartz in the Kakkonda geothermal field. 1997 Annual Meeting Geothermal Research Society of Japan, Abstracts with Programs, A19 (in Japanese).

Kissin, S.A. (1974) Phase relations in a portion of the $\mathrm{Fe}-\mathrm{S}$ system. Ph.D. Thesis, University of Toronto, Canada.

Koshiya, S., Okami, K., Kikuchi, Y., Hirayama, T., Hayasaka, Y., Uzawa, M., Honma, K. and Doi, N. (1993) Fracture system developed in the Takinoue geothermal area. Journal of the Geothermal Research Society of Japan, 15, 109139 (in Japanese with English abstract).

Muramatsu, Y. and Komatsu, R. (1995a) Fluid evolution in the Kakkonda shallow geothermal reservoir, Iwate prefecture, northeastern Japan: a fluid inclusion study. Journal of Mineralogy Petrology and Economic Geology, 91, 145161 (in Japanese with English abstract).

Muramatsu, Y. and Komatsu, R. (1995b) Fluid activity after intrusion of the Matsuzawa tonalite at the Kakkonda geothermal field, Iwate prefecture, northeastern Japan: a fluid inclusion study. Abstracts with Programs 1995 Joint Annual Meeting The Society of Mining Geology, The Mineralogical Society of Japan and The Japanese Association of Mineralogists, Petrologists and Economic Geologists, 118 (in Japanese).
Muramatsu, Y. and Komatsu, R. (1996) Fluid evolution in the Kakkonda shallow geothermal reservoir, Iwate Prefecture, Northeastern Japan: a fluid inclusion study. Journal of Mineralogy, Petrology and Economic Geology, 91, 145-161 (in Japanese with English abstract).

Muramatsu, Y., Komatsu, R., Sawaki, T., Sasaki, M. and Yanagiya, S. (2000) Geochemical study of fluid inclusions in anhydrite from the Kakkonda geothermal system, northeast Japan. Geochemical Journal, 34, 175-193.

Nakamura, H. and Sumi, K. (1981) Takinoue geothermal field. Field excursion guide to geothermal fields of Tohoku and Kyushu: Part I Geothermal fields of Tohoku (Volcanological society of Japan), 13-21.

Sato, K. (1982) Analysis of geological structure in the Takinoue geothermal area. Journal of the Geothermal Research Society of Japan, 3, 135-148 (in Japanese with English abstract).

Tamanyu, S. (1980) Radiometric dating of igneous rocks in the Sengan area. In: Research on hydrothermal system. Interim Rpt. Japan's Sun-Shine Project, FY 1978-1979, Geological Survey of Japan, 15-23 (in Japanese with English abstract).

Toulmin, P.III and Barton, P.B.Jr (1964) A thermodynamic study of pyrite and pyrrhotite. Geochimica et Cosmochimica Acta, 28, 641-671.

Truesdell, A.H. (1976) Summary of section III-Geothermal techniques in exploration. Proc. 2nd U.N. Symp. on the Development and Use of Geothermal Resources, San Francisco, 1975, 1, 1iii-1xxix.

Uchida, T., Akaku, K., Sasaki, M., Kamenosono, H., Doi, N. and Miyazaki, S. (1996) Recent progress of NEDO's "Deep-seated geothermal resources survey" project. Geothermal Resources Council Transactions, 20, 643-648.

Manuscript received; 20 December, 1999

Manuscript accepted; 6 March, 2000 